\title{
Pathway to Quality: Incorporating Students' Perceptions in the University Learner Support System
}

Richard Ouma: Directorate of Quality Assurance, Uganda Martyrs University, Kampala, Uganda.

ABSTRACT: The provision of learner support is pivotal in understanding the development trend in distance education. A survey of the literature indicates limited incorporation of the student perspective in learner support strategies in Open and Distance Education in Uganda. To investigate the students' perspective of the university learner support practices, this study used a quantitative approach involving a 45 questionnaire items to collect the students' views. Using factor analysis technique, findings from the study revealed four constructs of learner support, namely; academic advising support, library and technology support, counselling and career support, and communication service support. The study concludes that analysing and incorporating the views of the students in decision making at faculty and institution level help to consolidate learner support efforts, nurtures a relevant learner support culture and creates a pathway to improved learning in Open and Distance Education. It therefore recommends that the views/voice of the students should be considered in the planning and delivery of Open and Distance Education. In addition, investment in affordable ICTs is key to the effectiveness of learner support management and delivery in Open Distance Education.

Key words: Open, Distance education, Students' perceptions, Learner support, Factor analysis.

\section{Introduction}

Globally, the role of learner support in distance education cannot be underestimated (Brindley, 2014; Tait, 2000). Although efforts to enhance learner support in distance education are seen in both developed and developing countries, there are some differences in the nature of service delivery. In the USA for instance, the Institute for Higher Education Policy of USA focuses learner support in distance education on issues of institutional support (including electronic security measures like password protection, encryption and back-up systems); course development (involving guidelines used in course development, design, and delivery, and review of instructional materials); teaching and learning (including students' interaction with tutors and peers through a voice-mail, e- mail, feedback on assignments, and methods of effective research); course structure (outlining course objectives, concepts, and learning outcomes); student support (information on admission requirements, tuition, books); faculty support (tutor training and peer mentoring); and assessment (based on enrolment data, costs, innovative uses of technology, intended learning outcomes) (Phipps \& Merisotis, 2000; Stella \& Gnanam, 2004). Though these are considered the main learner support services to improve internet-based distance education, their provision varies between institutions depending on availability of support infrastructure like ICTs and staff skills. In the case of Federal universities in South Nigeria (Akpoiroro \& Okon, 2015) learner support services focus on security, medical services, library, and hostel, transport, and ICT services. In this case even socio- political environment influences the nature of learner support especially on issues of political security and transport which reflects the work and living environment in the developing countries especially in sub-Saharan

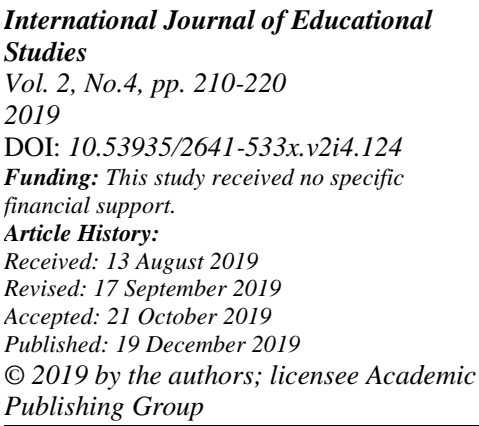
\begin{abstract}
Africa. Research indicate (Alves \& Uhomoibhi, 2010) that due to increased use of computers and web
\end{abstract}


applications such as blogs in distance education, security should be extended to such students' facilities to counter virus attacks. This challenge is faced by students world-over but prominent in developing countries where many students are novices in using computers and web applications.

In Uganda, efforts to improve learner support in distance education are yielding compared to the past. When correspondence courses were started in 1957 to up-grade Grade III teachers to Grade V, there was limited learner support which did not survive beyond 1962 (Senkomago, 2004). Bbuye and Mango (2005) posit that in the 1960s, Makerere University trained teachers on distance education mode and could use 'the people' newspaper to print and distribute the reading materials. Bbuye and Mango further claim that in addition to upgrading of Grade III teachers to Grade IV, other correspondence courses included good letter writing and the clerical entrance course. It is not clear how the learners were supported to send their work for marking and how they obtained feedback from the trainers. The training programme lacked clear direction given that the trainers like their students, had limited knowledge and skills in running correspondence courses.

With external funding, in the 1990s, the Ministry of Education through Kyambogo University improved learner support for distance education in-service teachers. Notable among these teacher training projects (Aguti, 2003; Bbuye \& Mango, 2005) included: the Mubende Integrated Teacher Education Project (MITEP), the Northern Integrated Teacher Education Project (NITEP), the Rakai Integrated Teacher Education Project (RITEP), and the Teacher Development Management System (TDMS). All these short teacher trainings aimed at equipping in-service teachers with relevant skills to improve the quality of the primary school education system. Efforts to incorporate the students' views in planning such interventions are hardly seen in the literature.

In the wake of liberalisation of the economy in 1990s, several private universities came on board to provide distance education to in-service teachers at diploma and degree levels (Binns \& Otto, 2006; Senkomago, 2004). Those universities mainly rely on printed course materials in the form of modules, and short face-to-face sessions for learner support. In their studies, in-service teachers undertake activities like; collecting and reading modules, doing coursework assignments, attending field support and regular face-toface sessions, sourcing information from the library and electronic sources, discussing with peers, consulting tutors, and doing examinations at the end of every semester. The use ICTs is encouraged especially mobile telephony and computers to facilitate research and communication. However, even if inservice teachers gained some knowledge in ICT use, only $8.5 \%$ of the 19,718 schools included in the national wide survey have computer laboratories and mainly located in urban areas (MoES, 2016). The implication is that about $64.5 \%$ of the schools (mainly rural-based) lack computer facilities.

The limited provision of basic tele-communications infrastructure and connectivity both at country and institutional level remains a problem in managing and delivering support to teacher trainees in Uganda (Mayende, Muyinda, Isabwe, Walimbwa, \& Siminyu, 2014). There has been a general increase in the number of students enrolling on the distance education mode in Uganda. For example; at UMU, the number has increased from 500 students (Lejeune, 2005) to over 2500 students (UMU, 2015). The increase is attributed to the need for job security, reducing on the high education costs, ensuring family stability, and continuing to serve the community unlike full-time programme that would withdraw one from his/her community (Senkomago, 2004). Such a practice is strengthened by the strong social ties and extended family culture of the African society such that the family, especially the children, spouses and elders, are not denied of their continuous services from the adult member studying.

\section{Drivers of Learner Support in Open and Distance Education}

2.1. Academic Learner Support Drivers

Provision of course materials is crucial in any learner support system of distance education. Delivering course materials in form of print, audio-visual, and electronic resources can ease their access by students and improve on learner support and learning. Studies conducted at the Open University of UK indicate that in order to ensure steady improvement in the quality of modules in distance learning, educational institutions have to build a database of their modules that should be continuously reviewed to improve service delivery and learning ( $\mathrm{Li}$, Kay, \& Markovich, 2018; Toetenel \& Rienties, 2016). The course materials should be relevant to the socio-cultural context of the students (Brigley, Hosein, \& Myemba, 2009). In Uganda, with much reliance on print study materials to support distance learners (Basaza, 
Milman, \& Wright, 2010; Leary \& Berge, 2007) efforts to improve on those study resources are needed for enhanced learner support.

Shimoni, Barrington, Wilde, and Henwood (2013) consider face-to-face workshops and group discussions key learner support services in distance education. This is because they provide academic and tutorial support, learning strategies and writing skills. Like in Nepal (Pangeni, 2016) Uganda's education culture is dominated by face-to-face tutoring. Distance education in Uganda features learning activities supported by face-to-face sessions and some on-line learning activities which is termed 'blended learning' (Mtebe, Dachi, \& Raphael, 2011). In his investigative study at the University of South Africa, Olivier (2016) found that students that attended face-to-face contact sessions performed better in written assignment compared to those who only participated in on-line discussion forums. Similarly, in 2 quantitative and 1 qualitative studies by Price, Richardson, and Jelfs (2007) at the Open University, UK, students that received face-to-face tuition reported better experiences than those that received on-line tuition. Conversely, in their comparative study of students' views on on-line and face-to-face support in Turkey; Sad, Goktas, and Bayrak (2014) found that students who received on-line support were more positive on key issues like programmes providing lifelong learning and having better opportunities to access and share learning resources than those who received face-to-face support. It can be argued that face-to-face and on-line support complement each other in learner support and require good preparation to have meaningful impact in a blended distance education system.

There is need to devote more time and resources on professional courses that strengthen knowledge and skills on teaching methods (Shimoni et al., 2013). Shen, Cho, Tsai, and Marra (2013) reason that distance learners should be aided to develop self-discipline, become confident in applying pedagogies and using different resource materials. There is need to revamp traditional modes of delivery to suit the technological needs of distance learners (Hadjinicolaou, 2014; Tagoe, 2012). The implication is that to succeed in technology use in learner support, there is need for a committed and high quality teaching and support staff Duranton and Mason (2012). In a wider perspective, Tait (2014) argues for integration of student support, curriculum design and delivery by the tutor in the digital age. Tait's view would necessitate extra training of the tutor not only to be able to effectively use the ICTs but also to have a broader understanding of the scope of learner support.

Regarding students' research supervision, several studies (Andrew, 2012; Manyike, 2017; Nasiri \& Mafakheri, 2014) indicate that there is a disconnection between the supervisor and the supervisee in open and distance education due to distance and spatial differences. Mapolisa (2012) study in Zimbabwe found that distance learners were supported by supervisors who had limited research skills, got little direction and had few supervision meetings that led to low quality research. Supervision is worse where the supervisor and supervisee live in different countries with an imbalance in availability of IT support (Sussex, 2008). Even within the same country, there can be variations in IT access by the students depending on whether one lives in a town or rural area as the case in Uganda. This has been termed as 'dancing at a distance' (Evans \& Green, 1995). In their studies (Andrew, 2012; Könings et al., 2016; Wright \& Griffiths, 2010) acknowledge that students' supervision and giving feedback is challenging in distance education and stress the role of the internet through mobile telephony, asynchronous email, skype and videoconferencing to optimise learner research supervision.

While several studies (Hampel \& de los Arcos, 2013; Ololube, 2006; Tagoe, 2012) underscore the role of ICT infrastructure through integration of various media, including ICT to support course delivery and student learning, the ICT infrastructural development remains problematic in several developing countries (Mwalongo, 2011). Shimoni et al. (2013) posit that technology support should involve providing the facility and teaching the students how to use it. Students' proficiency in the use of technologies depends on the support received (Floyd, 2018; Tagoe. \& Abakah, 2014). Several commentators (Bertin \& Narcy-Combes, 2007; Lee, 2003) observe that the use of technologies needs monitoring to elicit pedagogic and psychological support to erase a feeling of isolation especially when learner support is on-line. Even in the use of simple technologies like radio, mobile telephony, visual and print materials in distance education, learner support is needed for efficiency (Potter \& Naidoo, 2006). Research indicate a positive correlation between learners' satisfaction and technology perception (Drennan, Kennedy, \& Pisarski, 2005; Teeroovengadum, Heeraman, \& Jugurnath, 2017). Library support is the most critical of all the learner support services in distance education (Mayende \& Obura, 2013). This is because the library is the source

Studies

2019

DOI: $10.53935 / 2641-533 x . v 2 i 4.124$

Funding: This study received no specific

financial support.

Article History:

Revived: 13 August 2019

Revised. 17 September 2019

Accepted: 21 October 2019

(C) 2019 by the authors; licensee Academic Publishing Group 
of resources for learner research to complete the course assignments. The library provides electronic materials like e-journals, e-books and newspapers that can be accessed anywhere as long as one has access to internet connection. Therefore, distance learners should be entitled to library resources in their fullest for quality learning (Lee, 2003). While drawing examples from Australia, America and UK, Mears and Clough (2015) posit that from the library, the needs of distance learners go beyond journals and books and include how to support them to conduct individual-driven library research including the disabled students. Research found a strong correlation between library resources use and students' academic performance (Cox \& Jantti, 2014; Needham, Nurse, Parker, Scantlebury, \& Dick, 2013).

\subsection{Non Academic learner Support Drivers}

Based on studies carried out in several African countries (Botswana, Lesotho, Namibia, South Africa, Swaziland, Zambia, and Zimbabwe), Letseka (2016) argues that learner support in distance education can be improved by applying the philosophy of Ubuntu. Letseka states that Ubuntu is an African world view that encompasses moral values like compassion, kindness, dignity, generosity, benevolence, care and respect for other people. With its emphasis on the ethics of care to the students, Ubuntu philosophy is ideal for ensuring interactive learner support in distance education (Rampa \& Mphahlele, 2016). Though Ubuntu values are a common knowledge among the Bantu people of Africa (including my own society), putting those values in practice is not definite. In his episode about enhancing quality in ODL, (Mahlangu, 2016) contends that Ubuntu approach if followed, it enhances quality assurance by creating enabling environment for the students and staff to be fair, trustworthy, and respectful to others. The implication is that to make Ubuntu philosophy practical, the university should nurture an enabling environment by preparing both staff and students to embrace the above values. The fact that there are student-staff interactions in distance education as co-learners, and having emotional connection especially during research supervision, then, they should be considered members of Ubuntu (Ngubane-Mokiwa, 2016; Okada, Rabello, \& Ferreira, 2014). Therefore, embedding Ubuntu value of care and concern for each other in the training of both teacher trainers and trainees could be ideal to improve on learner support.

The need for a reliable communication system to easy communication between the faculty and the students has been emphasised (Gay, Mahon, Devonish, Alleyne, \& Alleyne, 2006; Wells \& Wells, 2007). This is because timely communication to distance learners can counteract a feeling of isolation from the instructor and peers (Bates, 2005; Puri, 2006). argue that for effectiveness, there is need for communication mapping and management in learner support so that there is clarity on the chain and levels of communication between the institution and the students. Tait and Mills' argument can help sort out the communication mess in distance education especially when there are several offices handling distance education issues like in most Ugandan universities (Bbuye, 2006). As a safeguard against communication lapses, several researchers (Douce, 2018; Gay et al., 2006) observe the need to use internet facilities like email, asynchronous discussion boards, synchronous chat rooms and skype in distance education.

In his survey of learner support in distance education, Dirr (1999) considers admissions and registration key pre-enrolment support services. Universities should ensure organised and transparent admissions and registration of the students (Shimoni et al., 2013). The implication is that admissions should be timely communicated to the students through known channels. While referring to Makerere University in Uganda, Muyinda (2012) claims that pre-enrolment learner support is only limited to advertising the courses. The students' registration is mainly done at university campuses and tend to be tedious with long queues that take a lot of students' time during face- to-face period. It could be prudent for the registry department to make its presence effectively felt by planning for on-line registration.

Orientating new students in distance education is one of the initial learner support services to enhance quality (Shimoni et al., 2013). The initial experience of students with distance education is frightening, frustrating and intimidating if they are not supported to develop self-confidence. In their investigation of distance education students' on-campus and on-line orientation study at the University of Manchester in the UK, (Forrester, Motteram, Parkinson, \& Slaouti, 2005) looked at orientation as the process of helping distance learners settle and embark on their studies. They further noted that effective orientation programme helps the university attract, ease transition and help students to concentrate and succeed in their studies. In Uganda, Mayende. and Obura (2013) highlight that given the adult nature of distance learners, who also live far from the universities with family and career commitments, they need orientation support

Studies

2019

DOI: $10.53935 / 2641-533 x . v 2 i 4.124$ Funding: This study received no specific financial support.

Article History:
Received: 13 August 2019

Revised: 17 September 2019

Accepted: 21 October 2019

Published: 19 December 2019 Publishing Group 
in lifelong learning skills. Provision of counselling and guidance services is a key learner support in distance education (Moore \& Kearsley, 2005). Like any other student, distance learners have academic, personal and career challenges that need services of a trained counsellor. However, inadequate counselling and guidance to distance learners has been reported in studies conducted in both high income and low income countries (Gujjar, Naoreen, \& Chaudhry, 2010; Kishore, 2014). For effectiveness in service delivery, there should be modern ICTs use (like computer aided guidance and counselling) in learner support, and students should be provided with one- on-one access to counsellors (Ludwig-Hardman \& Dunlap, 2003; Tait, 1999). Creating a sense of institutional belonging for distance learners through support services like student leadership representation, providing medium for networking with colleagues and lecturers, and easy access to course materials is a key learner support (Shimoni et al., 2013). In their episode, Ludwig-Hardman and Dunlap (2003) urge universities to guard students against isolation from their university, instructors and fellow peers. Distance learners' sense of belonging is enhanced through their representation in the students' leadership, having discussions with other students and staff, and inviting them to participate in some workshops or celebrations at campus. An interesting example is the weekend programme organised by the Eastern Oregon State Colleges where distance learners visit the campus on weekends and share experiences with peers and their lecturers. Lefever and Currant (2010) argue that technology through networking sites, SMS, and Instant Messaging (IM) can be used to create a better sense of university community belonging while saving the time a student would use to move to the university to meet peers (for peer mentoring and discussions) and staff (for consultations).

Dirr (1999) and Rumajogee, Jeeroburkhan, Mohadeb, and Mooneesamy (2003) indicate the need for an established distance education support department equipped with facilities and staff to support the students. Basics like a helpdesk and hotline must be in place. An innovative example is the 'follow the sun' help desk approach that enables universities in different continents to provide shared learner support to their students 24/7 issues of learner support collaboratively to ensure that students from all the concerned institutions could have their problems sorted out without delay. The other approach is for universities to develop their websites and provide sufficient support on- line so that students can serve themselves at a distance. The essence is that regardless of the location of the service provider, the learner support trend in distance education necessitates improved ICT infrastructure and access by both staff and students

\section{Methods}

The study population was 560 participants $(\mathrm{N}=560)$. It considered all the in-service primary school teachers enrolled at the Uganda Martyrs University. In line with, the nature and size of the study population were specified to give a clear picture of the scope of the investigation. A representative sample 320 respondents was targeted $(\mathrm{n}=320)$ (Newby, 2010). Based on the programmes strata in the faculty of Education, distance education programmes for in-service teachers were purposively selected (Walsh, 2001).The sample size was determined by the number of all first year students on the two programmes (BED 1 (210) and DEP 1 (110). First year students were selected because the study design aimed at following up and studying the same respondents after this study before completing their courses. 304 respondents returned the filled questions reflecting 95\% response rate and the case to variable ratio of 6.8:1 (304 cases against 45 variables). The study used self-administered questionnaires to collect data from 320 students engaged in distance education during face-to-face residential workshop at the training university. A 45 items questionnaire was used to collect the students' views, and the questions were measured on a five-point Likert type scale ranging from 1 (highly disagree) to 5 (highly agree). The same questionnaire was used to collect the demographic data of students focusing specifically on their distribution by gender, programmes of study, and school affiliation. The draft questionnaire was piloted on an independent group of 30 students which informed improvement of the questionnaire based on the input of the pilot study specifically providing clear choices on a five-point Likert scale.

\section{Data Analysis}

SPSS version 25 was used in data analysis. Descriptive statistics specifically frequencies and percentages were computed for the respondents' distribution by gender, programmes of study, and school affiliation. Factor analysis statistical technique was used to categorise the students' responses on dimensions derived from the data. The purpose of using factor analysis technique was to explore the 
possibility of reducing a large set of 45 variables on learner support to fewer manageable factors that are able to represent and explain the total number of variables (Field, 2009). It helped to unveil patterns in the correlation between the 45 variables on learner support. Only variables with a loading of .3 and above on a specific factor were considered when naming the factor (Hair, Babin, Anderson, \& Black, 2013).

The suitability of the data for factor analysis was examined. The correlation matrix revealed many coefficients of .3 and above. Normality was tested using normality plots with tests and histogram and the scores showed reasonably normal distribution. Likewise, the normal probability plots (Normal Q-Q Plots) showing the relationship between observed value and the normal distribution expected value (Pallant, 2010) indicated fairly straight line; an indication of normal distribution. The SPSS statistical output revealed straight-line relationships between the variables (linear relationships).

Multicollinearity was not detected among the variables with the determinant of the $R$-matrix of .0008676 which is $>.00001$ (Allen, Bennett, \& Heritage, 2014; Field, 2013). This implies that the variables did not correlate highly. Additionally, no outliers were detected among the cases. Detection of reasonably normal distribution, linearity and lack of outliers and multicollinearity in the data; showed the suitability of using factor analysis. The adequacy of the sample in the analysis was verified using the Kaiser-MayerOlkin (KMO). The KMO value was .865 (great as per (Field, 2009), and it is >.6 (Allen et al., 2014; Kaiser, 1974). Bartlett's Test of Sphericity was statistically significant with $p=.000$ which is <.05 (Bartlett, 1954).

Table-1. Reliability of Results Test.

\begin{tabular}{lllc}
\hline & Factor/construct & Question number & Cronbach's Alpha ( $\boldsymbol{\alpha})$ \\
\hline 1 & Academic advising support & $23,43,41,42,21,3,22,1,28,32,9$, & 0.854 \\
& & $34,27,24,33,35,11,26$ & \\
2 & Library and technology support & $15,31,30,13,10,16,20,14,8$ & 0.831 \\
3 & Counselling and career support & $37,38,36,40,25,44,39,17,29$, & 0.803 \\
4 & Communication service support & $5,12,6,7,45,4,2,18,19$ & 0.704 \\
\hline \multicolumn{2}{l}{ Note: All constructs produced a significant reliability with Cronbach's alpha $>.7$ (Field, 2009, 2013). }
\end{tabular}

Note: All constructs produced a significant reliability with Cronbach's alpha > .7 (Field, 2009, 2013).

Table-2. Students' distribution by gender, programmes of study, and school affiliation

\begin{tabular}{llcc}
\hline Items & Responses & Frequency & Percentage \\
\hline Gender & Not Answered & 3 & 1.0 \\
& Female & 144 & 47.4 \\
& Male & 157 & 51.6 \\
Programme of Study & Not Answered & 4 & 1.3 \\
& Bachelor of Education & 197 & 64.8 \\
& Diploma in Education & 103 & 33.9 \\
Ownership of School & Not Answered & 218 & 0.7 \\
& Public & 84 & 71.7 \\
Total for each Item & Private & 304 & 27.6 \\
\hline
\end{tabular}

\section{Findings}

\subsection{Students' Distribution by Gender}

The respondents' background information showed that out of the 304 students, $47.4 \%$ were females, $51.6 \%$ were males, and $1 \%$ preferred not to indicate their gender identity. The slight difference between the male and female participants is an indication of the increasing number of females in the teaching profession in Uganda and their efforts to use distance education to foster professional and career growth. The literature indicates that $59.5 \%$ of the registered primary school teachers are males and $40.5 \%$ are females in Uganda (MoES, 2009). This gender distribution of teachers in Uganda contrasts the common experience in many countries where primary school teaching is a heavily female-dominated profession. For example, in Europe, female teachers account for over $85 \%$ of the teachers in primary schools (Eurostat, 2016).

International Journal of Educational Studies 2019

DOI: $10.53935 / 2641-533 x . v 2 i 4.124$ Funding: This study received no specific financial support. Article History:

Revised: 17 Septort 2019

Revised. 17 September 2019

Published: 19 December 2019

(C) 2019 by the authors; licensee Academic Publishing Group 


\subsection{Study Programmes}

The study found that $64.8 \%$ of the students were doing a bachelor of education, $33.9 \%$ were on the diploma in education, and $1.3 \%$ did not indicate their programmes of study. The results indicate a bigger enrolment of students on the bachelors compared to the diploma programme. This is partially attributed to the government's ultimatum for all headteachers in public schools to have a minimum of a bachelor's degree by 2018 (MoES, 2011). Some experienced teachers enrolled to have a bachelor's degree in education to increase their chances of being appointed deputy headteachers if opportunities for career promotion arise.

\subsection{School Affiliation}

The study found that $71.7 \%$ of the students were teaching in public schools, $27.6 \%$ in private schools, and $0.7 \%$ did not indicate their school affiliation. The results indicate that the majority of the in-service teachers were employed by the government. It could be attributed to the tendency of most private schools to employ already highly trained and qualified teachers in order to maintain and sustain higher academic performance standards to compete favourably at national level and be able to attract more pupils in Uganda.

\subsection{Factor Analysis}

The study used a factor analysis to determine if the variables on learner support perceived by the students could be categorised. Using the Scree plot criterion (Cattell, 1966; Ledesma, Valero-Mora, \& Macbeth, 2015) 4 constructs emerged in the results (Table 3). Field (2009); Field (2013) advises to use a Scree plot when you have a sample exceeding 200 cases.

A 45 item questionnaire of the students' perceived quality of support was subjected to the principal components analysis (PCA) with oblique rotation (direct oblimin) using SPSS Version 25. Oblique rotation (direct oblimin) was used rather orthogonal rotations because the study involved humans (in-service teachers) whose psychological constructs are in any way related (Field, 2009; Tagoe \& Abakah, 2014).

Since pattern matrix reports factor loading for oblique rotation (Allen et al., 2014) and it highlights the unique contribution of each variable to a factor (Field, 2009, 2013) it was used to extract the results. The factor loadings less than .3 have been suppressed (Pallant, 2010). This led to the extract of 4 factors. Factor 1 had a loading of 18 variables, Factor 2 had 10, Factor 3 had 9, and Factor 4 had 8 variables Table 3.

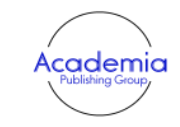

International Journal of Educational Studies

Vol. 2, No.4, pp. 210-220

2019

DOI: $10.53935 / 2641-533 x . v 2 i 4.124$

Funding: This study received no specific

financial support.

Article History:

Received: 13 August 2019

Revised: 17 September 2019

Accepted: 21 October 2019

Published: 19 December 2019

(C) 2019 by the authors; licensee Academic Publishing Group
Table-3. Pattern Matrix of students' perceived learner support quality.

\begin{tabular}{ll}
\multicolumn{2}{c}{ Table-3. Pattern Matrix of students' perceived learner support quality. } \\
\hline Item & $\begin{array}{l}\text { Loadings } \\
\text { Factor 1 Factor 2 Factor 3 Factor 4 }\end{array}$ \\
\hline 23. There is provision of Quality Modules & 0.699 \\
43. Timely feedback on coursework and exams & 0.621 \\
41. Course Evaluations are conducted & 0.543 \\
42. Instructors give comments on Coursework & 0.525 \\
21. Academic support/It is easy to access my instructions & 0.524 \\
3. Orientation/Induction in distance education is provided & 0.491 \\
22. Instructional Support/Face to face workshops organised & 0.473 \\
1. Adequate information on Admissions is provided & 0.469 \\
28. Students are given test /examination taking tips & 0.459 \\
32. Introduced to new subject content & 0.458 \\
9. Faculty/Student Handbook is provided & 0.456 \\
34. Field support is given by Staff & 0.448 \\
27. Students are given study tips / guides & 0.437 \\
24. Modules and Coursework are given in time & 0.433 \\
33. Taught variety of teaching methods / Pedagogy support & 0.409 \\
35. There is effective School Practice supervision - Diploma & 0.366 \\
11. "Successful Start Learner" Workshop is organised & 0.359 \\
26. Networking / Easy to interact with fellow learners & 0.357 \\
15. Library use and information search orientation is given & \\
31. Accessing Library Materials is easy & \\
30. Computers with Internet are availed & \\
\hline
\end{tabular}

Basing on the components of each factor, the four factors were named: 
1. Academic advising support

2. Library and technology support

3. Counselling and career support

4. Communication service support.

\section{Discussion}

The strong loading of academic advising support from factor analysis highlights the students' perceptions that the faculty had supported them mainly on academic issues manifested in form of provision of modules, giving timely feedback on coursework and exams, conducting course evaluations, instructors giving comments on coursework, easy to meet the instructors, provision of induction and face-to-face workshops; provision of adequate information on admissions, giving examinations taking tips, introduction of new subject content, provision of faculty/student handbook, giving field support and study guides; giving modules and coursework in time; pedagogy support and effective school practice provision; and easy to interact with fellow learners. In this case, the surrogate variable (one with the highest factor loading) is provision of modules with a factor loading of .699; and easy to interact with fellow learners had lowest factor loading of .357 . The results imply that there was much reliance on printed course materials in the study. This finding is consistent with that of Basaza et al. (2010) which revealed print materials as the predominant medium of teaching in Uganda and the sub-Saharan Africa. Conversely, with a lowest factor loading of .357 , the finding on easy to interact with fellow learners corroborates those of and Mayende et al. (2014) which point out the limited use ICTs in learner-learner interaction in Uganda. The implication is that limited interaction among learners could be influenced by a limited use of modern technologies in enhancing communication and interaction in distance education.

The study findings support the claim that the library and ICT are critical learner support services in distance education (Mayende \& Obura, 2013). The output of factor analysis revealed a surrogate variable (library use and information search) factor loading of -.773. The implication is that the students valued the library in their information search and research and appreciated the efforts of the university to provide such services. This finding is not consistent with that of which point out the limited use ICTs in learner support in Uganda. But, with the increasing use of mobile phones in Uganda (Mayende et al., 2014) the trend in use of social media for communication and learning is positive. However, provision of information on scholarships was ranked lowest with a factor loading of -.397. This finding reflects that in the study context, issues of finding and notifying the students about possible funding opportunities for their studies were rare. Nevertheless, in view that there is a strong correlation between library resources use and students' academic performance (Cox \& Jantti, 2014; Needham et al., 2013) and a positive correlation between learners' satisfaction and technology perception (Drennan et al., 2005) distance education providers in Uganda should strategically plan for the provision of the library and ICTs facilities to nurture a supportive learning environment. Although the importance of the students' counselling programme has been emphasised in the literature on distance education (Moore \& Kearsley, 2005; Shimoni et al., 2013) the findings revealed a low perceived quality of counselling and career support in the study. It was the second last factor in factor analysis results; reflecting the paucity of counselling and career guidance for the students. This demonstrates that there is no special programme organised by the faculty to prepare and counsel the students to cope with the learning needs of distance education. As observed by Gujjar et al. (2010) and Kishore (2014) there is no income divide between countries on issues of learner counselling difficulties; counselling support inadequacy has featured in both high income and low income countries. Nonetheless, developing countries like Uganda, find it harder to effectively counsel and support the increasing number of students enrolled on distance education due to limited material and skilled human resources. To transform the trend of counselling and career support in distance education, investing in human development and increased use of ICTs are commendable pathways (Ludwig-Hardman \& Dunlap, 2003; Tait, 1999).

With respect to communication service support, the study found that it had the least rating in terms of students' perceived quality. This was evidenced by its surrogate variable (provision of functional help desk) having a factor loading of only .593 in factor analysis. Provision of suggestion box for the students had the lowest factor loading of .311 , implying that it was the least provided communication support. Overall, the results suggest that communication service support was perceived to be very weak by the students compared to the provision of other learner support services by the university. In addition, its factor loadings 
were lower compared to the loadings on other factors in factor analysis. Results indicate that communication between the faculty and the students, and among the students is limited and could be an impediment to effective learner support in the study. Results support the study of Bbuye (2006) which revealed communication challenges in distance education in Uganda. It can be inferred that the learners' views on communication support showed a substantial perceived discomfort that impedes on their academic progress. As a central learner support to counteract a feeling of isolation from the instructor and peers among the students, the faculty ought to ensure that communication channels and systems are clear and user friendly (Bates, 2005; Puri, 2006).

\section{Conclusion}

The study aimed at investigating in-service teachers' perceptions of the learner support quality by the training university. Results indicate that the students obtained higher quality academic advising support compared to all the other three support services (library and technology, counselling and career, and communication support services). From factor 1 to 4 in the results, the learner perceived quality of support decreases. It can be claimed that communication service support is perceived by the students to be the least adequately provided compared to the other learner support services in the study.

For effective learner support delivery, it is advisable for universities offering distance education programmes to assess their respective capacity and ability to support their learners. The views of the students as end-users of the university learner support should be regularly sought and incorporated in decision making at institutional policy level. The implication is that nurturing a relevant learner support system and practices should be informed by the different institutional stakeholders especially the students as the ultimate beneficiaries. Otherwise, it could be illogical to develop a learner support system without involving the learners. In line with the notion of management becoming an ally and enhancing cooperation among groups of stakeholders in learner support concerted efforts of the faculty, students and institutional managers is essential to develop a sustainable learner support system.

\section{References}

Aguti, J. N. (2003). A Study of in-service distance education for secondary school teachers in Uganda: Developing a framework for quality teacher education programmes. Retrieved from: http://hdl.handle.net/10570/1754. [Accessed December 12, 2018].

Akpoiroro, R. M., \& Okon, J. E. (2015). Students satisfaction with service delivery in federal universities in South-south geo-political Zone, Nigeria. International Journal of Educational Administration and Policy Studies, 7(5), 110-113.

Allen, P., Bennett, K., \& Heritage, B. (2014). SPSS Statistics version 22: A practical guide. Sydney: Cengage Learning.

Alves, P., \& Uhomoibhi, J. (2010). Issues of e-learning standards and identity management for mobility and collaboration in higher education. Campus-Wide Information Systems, 27(2), 79-90.

Andrew, M. (2012). Supervising doctorates at a distance: three trans-Tasman stories. Quality Assurance in Education, 20(1), $42-53$.

Bartlett, M. S. (1954). A note on the multiplying factors for various $\chi 2$ approximations. Journal of the Royal Statistical Society. Series B (Methodological), 16(2), 296-298

Basaza, G. N., Milman, N. B., \& Wright, C. R. (2010). The challenges of implementing distance education in Uganda: A case study. International Review of Research in Open and Distributed Learning, 11(2), 85-91.

Bates, A. W. (2005). Technology, e-learning and distance education (2nd ed.). London: Routledge.

Bbuye, J. (2006). Towards developing a framework for support services for Universities in Uganda. Kampala: Makerere University, Department of Distance Education.

Bbuye, J., \& Mango, M. J. (2005). Origin and trend of distance education in Uganda. Journal of Social Sciences, 1(3), $166-171$.

Bertin, J.-C., \& Narcy-Combes, J.-P. (2007). Monitoring the learner-who, why and what for? Computer Assisted Language Learning, 20(5), 443-457.

Binns, F., \& Otto, C. (2006). Quality assurance in open distance education - towards a culture of quality: A case study from Kyambogo University. Vancouver: The Commonwealth of Learning.

Brigley, S., Hosein, I., \& Myemba, I. (2009). Bridging the divide: sustainability and relevance of a distance learning module for clinical officers in Tanzania. Open Learning: The Journal of Open, Distance and e-Learning, 24(2), 155-163.

International Journal of Educational Studies

Vol. 2, No.4, pp. 210-220

2019

DOI: $10.53935 / 2641-533 x . v 2 i 4.124$

Funding: This study received no specific

Funding: This st

financial support.

Article History:
Received: 13 August 2019

Received: 13 August 2019
Revised: 17 September 2019

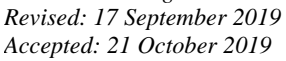

Published: 19 December 2019

(c) 2019 by the authors; licensee Academic

Publishing Group

Brindley, J. E. (2014). Learner support in online distance education: Essential and evolving. Online Distance Education. Towards a Research Agenda, 287-310.

Cattell, R. B. (1966). The scree test for the number of factors. Multivariate Behavioral Research, 1(2), 245-276.

Cox, B., \& Jantti, M. (2014). 'Discovering the impact of library use and student performance. EDUCAUSE Review, 1-7.

Dirr, P. J. (1999). Putting the principles into practice: Promoting effective support services for students in distance learning programs: A report on the findings of a survey. Project Report Funded by the U.S. Department of Education Fund for the Improvement of Postsecondary Education.

Douce, C. (2018). EDEN: Report on the European Distance education network (EDEN) Conference, 13-16 June 2017, Jönköping, Sweden. Open Learning: The Journal of Open, Distance and e-Learning, 33(1), 63-69.

Drennan, J., Kennedy, J., \& Pisarski, A. (2005). Factors affecting student attitudes toward flexible online learning in management education. The Journal of Educational Research, 98(6), 331-338. 
Duranton, H., \& Mason, A. (2012). The loneliness of the long-distance learner: social networking and student support. A case study of the distance-learning MA in translation at Bristol University. Open Learning: The Journal of Open, Distance and e-Learning, 27(1), 81-87.

Eurostat. (2016). Women teachers largely over-represented in primary education in the EU. Retrieved from: http://ec.europa.eu/eurostat/documents/2995521/7672738/3-04102016-BP- $\quad$ EN.pdf/9f0d2d04-211a-487d-87c3-0a5f7d6b22ce. [Accessed October 10, 2018].

Evans, T., \& Green, B. (1995). Dancing at a distance? Postgraduate studies, supervision, and distance education. Paper presented at the 25th Annual Conference of the Australian Association for Research in Education, Hobart, November 26-30.

Field, A. (2009). Discovering statistics using SPSS (3rd ed.). Thousand Oaks, CA: Sage Publications.

Field, A. (2013). Discovering statistics using SPSS (4th ed.). Thousand Oaks, CA: Sage Publications.

Floyd, D. L. (2018). 'Community college student affairs and student success'. Community College Journal of Research and Practice. Routledge, 42(11), 757-758.

Forrester, G., Motteram, G., Parkinson, G., \& Slaouti, D. (2005). Going the distance: Students' experiences of induction to distance learning in higher education. Journal of Further and Higher Education, 29(4), 293-306.

Gay, G., Mahon, S., Devonish, D., Alleyne, P., \& Alleyne, P. (2006). Perceptions of information and communication technology among undergraduate management students in Barbados. International Journal of Education and Development using ICT, 2(4), 6-17.

Gujjar, A. A., Naoreen, B., \& Chaudhry, A. H. (2010). A comparative study of student support services: The United Kingdom, Pakistan and Sri Lanka. Procedia-Social and Behavioral Sciences, 2(2), 839-846.

Hadjinicolaou, M. (2014). Virtual class-an appropriate environment for distance learning mathematics at an open university. European Journal of Open, Distance and E-Learning (EURODL), 17(1), 147-153.

Hair, J. F., Babin, B. J., Anderson, R. E., \& Black, W. G. (2013). Multivariate dataanalysis (7th ed.). Harlow: Pearson Education.

Hampel, R., \& de los Arcos, B. (2013). Interacting at a distance: A critical review of the role of ICT in developing the learner-context interface in a university language programme. Innovation in Language Learning and Teaching, 7(2), 158-178.

Kaiser, H. F. (1974). An index of factorial simplicity. Psychometrika, 39(1), 31-36.

Kishore, S. (2014). Academic counselling in ODL: Information system for capacity building of academic Counselors' in IGNOU. Turkish Online Journal of Distance Education, 15(2), 98-107.

Könings, K. D., Popa, D., Gerken, M., Giesbers, B., Rienties, B. C., van der Vleuten, C. P., \& van Merriënboer, J. J. (2016). Improving supervision for students at a distance: Videoconferencing for group meetings. Innovations in Education and Teaching International, 53(4), 388-399.

Leary, J., \& Berge, Z. (2007). Successful distance education programs in sub-Saharan Africa. Turkish Online Journal of Distance Education, $8(2), 136-145$

Ledesma, R. D., Valero-Mora, P., \& Macbeth, G. (2015). The scree test and the number of factors: A dynamic graphics approach. The Spanish Journal of Psychology, 18(11), 1-10.

Lee, J.-Y. (2003). Current status of learner support in distance education: emerging issues and directions for future research. Asia Pacific Education Review, 4(2), 181-188.

Lefever, R., \& Currant, B. (2010). How can technology be used to improve the learner experience at points of transition? Retrieved from: http://technologyenhancedlearning.net/files/2010/04/ELESIGliteraturereviewFINAL240210.pdf. [Accessed February 8, 2019].

Lejeune, M. (2005). Managing growth and maximising resources: The case of Uganda Martyrs University. In A. F. Brown (Ed.), Meeting the challenges of higher education in Africa: The role of private universities. Paper presented at the Conference proceedings at United States International University, Nairobi, Kenya.

Letseka, M. (2016). Open distance learning (ODL) and the philosophy of ubuntu. In M. Letseka (Eds.), Open Distance Learning (ODL) through the Philosophy of Ubuntu (pp. 1-16). New York: Nova Publishers.

Li, J., Kay, R., \& Markovich, L. (2018). Student attitudes toward blended learning in adult literacy and basic skills college programs. Canadian Journal of Learning and Technology/La revue canadienne de l'apprentissage et de la technologie, 44(2).

Ludwig-Hardman, S., \& Dunlap, J. C. (2003). Learner support services for online students: Scaffolding for success. International Review of Research in Open and Distributed Learning, 4(1), 1-15.

Mahlangu, V. P. (2016). Assuring quality in ODL through ubuntu. In M. Letseka (Ed.), Open Distance Learning (ODL) through the Philosophy of Ubuntu (pp. 107-118). New York: Nova Publishers.

Manyike, T. V. (2017). Postgraduate supervision at an open distance e-learning institution in South Africa. South African Journal of Education, 37(2), 1-11.

Mapolisa, T. (2012). Provision of research support services to ODL learners by tutors: A focus on the Zimbabwe open university's bachelor of education (Educational Management) research students' supervision experiences. Turkish Online Journal of Distance Education, 13(2), 58-68.

Mayende, G., Muyinda, P. B., Isabwe, G. M. N., Walimbwa, M., \& Siminyu, S. (2014). Facebook mediated interaction and learning in distance learning at Makerere University. Kampala: Department of Open and Distance Learning, Makerere University.

Mayende., J. E., \& Obura, C. O. (2013). Distance learning library services in Ugandan universities. Journal of Library \& Information Services in Distance Learning, 7(4), 372-383.

Mears, W., \& Clough, H. (2015). Online library accessibility support: a case study within the Open University Library. Open Learning: The Journal of Open, Distance and e-Learning, 30(1), 73-85.

International Journal of Educational Studies

Vol. 2, No.4, pp. 210-220

2019

DOI: $10.53935 / 2641-533 x . v 2 i 4.124$

Funding: This study received no specific

financial support.

Article History:

Received: 13 August 2019

Revised: 17 September 2019

Accepted: 21 October 2019

Published: 19 December 2019

(C) 2019 by the authors; licensee Academic

Publishing Group
MoES. (2009). Uganda education statistical abstract 2009. Kampala: Education Planning and Policy Analysis Department.

MoES. (2011). Uganda education statistical abstract 2011. Kampala: Education Planning and Policy Analysis Department.

MoES. (2016). The education abstract is a statistical report detailing the findings of the Annual School Census 2016. 205.

Moore, M. G., \& Kearsley, G. (2005). Distance education: A systems view (2nd ed.). Belmont, CA: Thomson/Wadsworth.

Mtebe, J. S., Dachi, H., \& Raphael, C. (2011). Students' experiences and challenges of blended learning at the University of Dar es Salaam, Tanzania. Distance Education, 32(2), 289-294.

Muyinda, P. B. (2012). Open and distance learning in dual mode universities: A treasure unexploited. International Perspectives of Distance Learning in Higher Education, 33-50.

Mwalongo, A. (2011). Teachers' perceptions about ICTs for teaching, professional development, administration and personal use. International Journal of Education and Development using Information and Communication Technology (IJEDICT), 7(3), 36-49. 
Nasiri, F., \& Mafakheri, F. (2014). Postgraduate research supervision at a distance: A review of challenges and strategies. Studies in Higher Education, 40(10), 1962-1969.

Needham, G., Nurse, R., Parker, J., Scantlebury, N., \& Dick, S. (2013). Can an excellent distance learning library service support student retention and how can we find out? Open Learning: The Journal of Open, Distance and e-Learning, 28(2), 135-140.

Newby, P. (2010). Research methods for education. London: Pearson.

Ngubane-Mokiwa, S. A. (2016). Delivering open distance e-learning through ubuntu values. In M. Letseka (Ed.), Open Distance Learning (ODL) through the Philosophy of Ubuntu (pp. 147-162). New York: Nova Publishers.

Okada, A., Rabello, C., \& Ferreira, G. (2014). Developing 21st century skills through colearning with OER and social networks. Paper presented at the European Distance and E-Learning Network 2014 Research Workshop, pp. 121-130.

Olivier, B. (2016). The impact of contact sessions and discussion forums on the academic performance of open distance learning students. International Review of Research in Open and Distributed Learning: IRRODL, 17(6), 75-88.

Ololube, N. P. (2006). Appraising the relationship between ICT usage and integration and the standard of teacher education programs in a developing economy. International Journal of Education and Development using Information and Communication Technology (IJEDICT), 2(3), 70-85.

Pallant, J. (2010). SPSS survival manual (4th ed.). Maidenhead: Open University Press.

Pangeni, S. K. (2016). Open and distance learning: Cultural practices in Nepal. European Journal of Open, Distance and E-Learning (EURODL), 19(2), 32-45.

Phipps, R., \& Merisotis, J. (2000). Quality on the Line: Benchmarks for Success in Internet-Based Distance Education: The Institute for Higher Eduction Policy.

Potter, C., \& Naidoo, G. (2006). Using interactive radio to enhance classroom learning and reach schools, classrooms, teachers, and learners. Distance Education, 27(1), 63-86.

Price, L., Richardson, J. T., \& Jelfs, A. (2007). Face-to-face versus online tutoring support in distance education. Studies in Higher Education, 32(1), 1-20.

Puri, A. (2006). Distance education. New Delhi: Pragun Publications.

Rampa, S. H., \& Mphahlele, L. K. (2016). Supporting open distance learning (ODL) students through Ubuntu values. In M. Letseka (Ed.), Open Distance Learning (ODL) through the Philosophy of Ubuntu (pp. 119- 132). New York: Nova Publishers.

Rumajogee, R., Jeeroburkhan, F., Mohadeb, P., \& Mooneesamy, V. (2003). Case study on distance education for teacher education in mauritius: Association for the Development of Education in Africa.

Sad, S. N., Goktas, O., \& Bayrak, I. (2014). A comparison of student views on web-based and face-to-face higher education. Turkish Online Journal of Distance Education, 15(2), 209-226.

Senkomago, N. S. (2004). Teacher education at a distance; impact on development in the community: Country report - Uganda. Cambridge: IEC.

Shen, D., Cho, M.-H., Tsai, C.-L., \& Marra, R. (2013). Unpacking online learning experiences: Online learning self-efficacy and learning satisfaction. The Internet and Higher Education, 19, 10-17.

Shimoni, R., Barrington, G., Wilde, R., \& Henwood, S. (2013). Addressing the needs of diverse distributed students. International Review of Research in Open and Distributed Learning, 14(3), 134-157.

Stella, A., \& Gnanam, A. (2004). Quality assurance in distance education: The challenges to be addressed. Higher Education, 47(2), 143-160.

Sussex, R. (2008). Technological options in supervising remote research students. Higher Education, 55(1), 121-137.

Tagoe, M. (2012). Students' perceptions on incorporating e-learning into teaching and learning at the University of Ghana. International Journal of Education and Development using ICT, 8(1), 91-103.

Tagoe., M. A., \& Abakah, E. (2014). Determining distance education students' readiness for mobile learning at university of Ghana using the theory of planned behavior. International Journal of Education and Development using Information and Communication Technology, 10(1), 91-106.

Tait, A. (1999). Face-to-face and at a distance: The mediation of guidance and counselling through the new technologies. British Journal of Guidance \& Counselling, 27(1), 113-122.

Tait, A. (2000). Planning student support for open and distance learning. Open Learning: The Journal of Open, Distance and e-Learning, 15(3), 287-299.

Tait, A. (2014). From place to virtual space: Reconfiguring student support for distance and e-learning in the digital age. Open Praxis, 6(1), 516.

Teeroovengadum, V., Heeraman, N., \& Jugurnath, B. (2017). Examining the antecedents of ICT adoption in education using an extended technology acceptance model (TAM). International Journal of Education and Development using ICT, 13(3), 4-23.

Toetenel, L., \& Rienties, B. (2016). Learning Design-creative design to visualise learning activities. Open Learning: The Journal of Open, Distance and e-Learning, 31(3), 233-244.

UMU. (2015). University prospectus 2015. Kampala: Maranunium.

Walsh, M. (2001). Research made real: A guide for students. Cheltenham: Nelson Thornes

Wells, R., \& Wells, S. (2007). Challenges and opportunities in ICT educational development: A Ugandan case study. International Journal of Education and Development using Information and Communication Technology (IJEDICT), 3(2), 100-108.

International Journal of Educational Studies

Vol. 2, No.4, pp. 210-220

2019

DOI: $10.53935 / 2641-533 x . v 2 i 4.124$

Funding: This study received no specific

financial support.

Article History:

Received: 13 August 2019

Revised: 17 September 2019

Accepted: 21 October 2019

Published: 19 December 2019

(C) 2019 by the authors; licensee Academic

Publishing Group
Wright, J., \& Griffiths, F. (2010). Reflective practice at a distance: Using technology in counselling supervision. Reflective Practice, 11(5), 693-703. 